\title{
Pengaruh Model Pembelajaran Langsung Berbantuan Media Gambar Terhadap Kompetensi Pengetahuan Matematika Siswa Kelas IV SD
}

\author{
Ni Pt. Risma Handayani ${ }^{1}$, I.B. Gede Surya Abadi ${ }^{2}$ \\ ${ }^{12}$ Prodi Pendidikan Guru Sekolah Dasar, FIP \\ Universitas Pendidikan Ganesha, Singaraja, Indonesia \\ e-mail: handayanirisma11@gmail.com1, idabagussurya.abadi@undiksha.co.id \\ Abstrak
}

Penelitian ini bertujuan untuk mengetahui pengaruh model pembelajaran langsung (direct intruction) berbantuan media gambar terhadap kompetensi pengetahaun matematika kelas IV SD Gugus Letda Made Putra Denpasar Utara. Penelitian ini merupakan penelitian eksperimen yang menggunakan desain eksperimen semu dengan rancangan kelompok non-equivalen. Populasi dalam penelitian ini seluruh siswa kelas IV SD Gugus Letda Made Putra yang berjumalah 6 sekolah. Teknik pengambilan sampel yang digunakan adalah random sampling. Sampel penelitian ini adalah siswa kelas IV SDN I Tonja sebagai kelompok eksperimen dengan jumlah 41 siswa dan kelas IV SDN 2 Tonja sebagai kelompok kontrol dengan jumlah 32 siswa. Metode pengumpulan data yang digunakan yaitu metode tes dengan instrument tes berbentuk pilihan ganda. Teknik analisis data yang digunakan adalah uji-t, hasil analisis data diperoleh $t_{\text {hitung }}=$ 5,998 dan dengan taraf signifikansi $5 \%$ dengan $\mathrm{dk}=41+32-2=71$ diperoleh $t_{\text {tabel }}=2,000$. Dengan demikianm, nilai $t_{\text {hitung }}>t_{\text {tabel }}$ sehingga $\mathrm{H}_{0}$ ditolak, berarti terdapat perbedaan yang signifikan terhadap kompetensi pengetahuan matematika siswa yang dibelajarkan dengan model pembelajaran langsung (direct instruction) berbantuan media gamabar dan siswa yang dibelajarkan dengan pembelajaran konvesional.

Kata Kunci: direct instruction, gambar, kompetensi matematika

\begin{abstract}
The aim of this research was to find out the effect of learning model Direct Instruction assisted with Pictures Media on mathematic competency on $4^{\text {th }}$ grade students of SD Gugus Letda Made Putra. This research used a quasi-experimental research with non-equivalent group design. The population took all $4^{\text {th }}$ grade students of SD Gugus Letda Made Putra which was consisted of 6 schools, 11 classes and 362 students. Random sampling technique was used in choosing the sample. The sample was $4^{\text {th }}$ grade students of SDN 1 Tonja which was consisted of 41 students as experimental group and $4^{\text {th }}$ grade students of SDN 2 Tonja which was consisted of 32 students as control group. In analysing the data, $t$-test was applied. The result of analysis showed that $t_{\text {count }}=$ 5,998 , with $5 \%$ of significance level and $d k=41+32-2=71$ obtained $t_{\text {table }}=2,000$. It could be said that $t_{\text {count }}>t_{\text {table }}$ so, $H_{0}$ was rejected. This means that there was a significant effect on mathematic competency between the students who were taught by using Direct Instruction assisted with pictures media and the students who were taught by using conventional method. It could be seen from the mean score.
\end{abstract}

Keywords: direct instruction, pictures, mathematical competency

\footnotetext{
*Corresponding author.
}

Received 20 January 2020, Accepted 20 March 2020; Available online 5 Appril 2020 (C) 2020 MI All Rights Reserved 


\section{Pendahuluan}

Pendidikan memegang peranan yang sangat penting dalam mempersiapkan sumber daya manusia yang berkualitas guna menjamin keberlangsungan pembangunan suatu bangsa. Peningkatan kualitas pendidikan di Indonesia ditandai dengan adanya penyempurnaan yang dilaksanakan oleh pemerintah pada setiap aspek pendidikan. Mulai dari pendanaan, pengembangan model pembelajaran, perbaikan sarana dan prasarana pendidikan hingga pembaharuan kurikulum. Kurikulum memang telah terjadi beberapa kali perubahan sebelum dikembangkannya kurikulum 2013. Pada penerapkan Kurikulum 2013 dalam proses pembelajarannya menggunakan pendekatan saintifik atau pendekatan ilmiah. Pembelajaran dengan pendekatan saintifik adalah proses pembelajaran yang dirancang sedemikian rupa agar peserta didik secara aktif mengkonstruksi konsep, hukum atau prinsip (Kumiasih dan Sani, 2014). Dalam proses pembelajaran, guru mempunyai tugas yang sangat penting, yaitu menentukan, merancang, dan melaksanakan model pembelajaran yang akan digunakan. Jadi, guru harus profesional dan kompeten dalam merancang serta melaksanakan tugasnya untuk membelajarkan siswa di kelas, dan meningkatkan kmopetensi pengetahuan matematika di SD.

Menurut Agung (2013:119), "kompetensi merupakan kemampuan penguasaan pengetahuan, sikap, dan keterampilan tentang suatu objek tertentu (suatu mata pelajaran)". Kompetensi adalah suatu yang kompleks yang di dalamnya mengandung banyak aspek. Pada kurikulum 2013, aspek tersebut dinyatakan di dalam rumusan kompetensi, diantaranya kompetensi inti 1 yaitu spiritual, kompetensi inti 2 yaitu sikap (afektif), kompetensi inti 3 yaitu pengetahuan (kognitif), dan kompetensi inti 4 yaitu keterampilan (psikomotor). Tujuan pembelajaran menggambarkan proses dan hasil belajar yang diharapkan dicapai oleh peserta didik sesuai dengan kompetensi dasar (Agung, 2013:119). Dengan demikian, maka kompetensi berkaitan dengan hasil belajar. Susanto (2013) hasil belajar dinyatakan sebagai perubahanperubahan yang terjadi pada diri siswa, baik yang menyangkut aspek kognitif, afektif, dan psikomotor sebagai hasil dari kegiatan belajar. Secara sederhana, yang dimaksud dengan hasil belajar siswa adalah kemampuan yang diperoleh anak setelah melalui kegiatan belajar.

Dari beberapa pendapat tersebut dapat disimpulkan bahwa hasil belajar siswa dapat dilihat dari kompetensi yang didapat siswa setelah mengalami proses belajar. Kompetensi pengetahuan dapat dengan jelas mengukur kemampuan siswa dalam memahami dan menguasai isi dari suatu materi atau bahan pelajaran. Kompetensi pengetahuan juga dapat dinyatakan sebagai kompetensi ranah kognitif yang mampu mengukur tingkat pencapaian siswa dalam aspek pengetahuan. Pada Permendikbud Nomor 104 Tahun 2014 kompetensi pengetahuan dinyatakan dengan skor tertentu untuk kemampuan berpikir dan dimensi pengetahuannya. Salah satu kompetensi pengetahuan siswa yang juga perlu diukur menggunakan nilai adalah kompetensi pengetahuan matematika.

Kata matematika berasal dari bahasa Latin, manthanein atau mathema yang berarti "belajar atau hal yang dipelajari," sedangkan dalam bahasa Belanda, matematika disebut wiskunde atau ilmu pasti, yang kesemuanya berkaitan dengan penalaran (Depdiknas, 2001: 7). Matematika memiliki bahasa dan aturan yang terdefinisi dengan baik, penalaran yang jelas dan sistematis, dan struktur atau keterkaitan antar konsep yang kuat. Unsur utama pekerjaan matematika adalah penalaran dedukti yang bekerja atas dasar asumsi (kebenaran konsistensi). Selain itu, matematika juga bekerja melalui penalaran induktif yang didasarkan fakta dan gejala yang muncul untuk sampai pada perkiraan tertentu. Tetapi perkiraan ini, tetap harus dibuktikan secara deduktif, dengan argumen yang konsisten. Matematika merupakan salah satu disiplin ilmu yang dapat meningkatkan kemampuan berpikir dan berargumentasi, memberikan 
kontribusi dalam penyelesaian masalah sehari-hari dan dalam dunia kerja, serta memberikan dukungan dalam pengembangan ilmu pengetahuan dan teknologi. Kebutuhan akan aplikasi matematika saat ini dan masa depan tidak hanya untuk keperluan sehari-hari, tetapi terutama dalam dunia kerja, dan untuk mendukung perkembangan ilmu pengetahuan. O1eh karena itu, matematika sebagai ilmu dasar perlu dikuasai dengan baik oleh siswa, terutama sejak usia sekolah dasar. Secara umum, tujuan pembelajaran matematika di sekolah dasar adalah agar siswa mampu dan terampil menggunakan matematika. Selain itu juga, dengan pembelajaran matematika dapat memberikan tekanan penataran nalar dalam penerapan matematika. Jadi, pembelajaran matematika merupakan suatu proses belajar mengajar dengan bahan matematika yang dapat mengajak siswa berpikir secara kritis, aktif, dan kreatif. Pada hakikatnya, matematika adalah ilmu deduktif yang abstrak, sedangkan anak usia sekolah dasar relatif berada pada pemikirian konkret dengan kemampuan yang bervariasi sehingga strategi dan pendekatan psikologi sebagai jembatan sementara adalah salah satu alternatifnya. Sesuai dengan pemaparan tersebut, dapat disimpulkan bahwa kompetensi pengetahuan matematika adalah kemampuan untuk menghadapi permasalahan dalam permasalahan matematika maupun dalam kehidupan nyata, atau merupakan kemampuan matematika untuk menggali pengetahuan dalam matematik, menyusun konjektur, berpikir secara logis, menyelesaikan masalah yang tidak rutin, mampu berkomunikasi dan membuat koneksi serta representasi dari topik dalam matematika.

Hasil wawancara di SD Gugus Letda Made Putra tahun ajaran 2018/2019 bahwa hampir 3-5 orang siswa belum memenuhi Kriteria Ketuntasan Minimal (KKM) di setiap kelasnya dimana siswa tersebut mendapatkan nilai di bawah 65 dalam mata pelajaran matematika. Dalam proses pembelajaran di gugus tersebut sudah diterapkannya Kurikulum 2013 dengan Pendekatan Saintifik tetapi belum maksimalnya model pembelajaran dan media yang digunakan guru dalam proses pembelajaran. Sehingga siswa kurang antusias dan kurang aktif mengikuti pelajaran pada mata pelajaran matematika, beberapa siswa nampak tidak fokus dan kurang bersemangat dalam mengikuti pembelajaran, pemahaman siswa tentang materi matematika masih kurang. Hal tersebut harus segera dicarikan solusi agar pembelajaran matematika dapat memenuhi kebutuhan peserta didik sehingga akan mendukung siswa dalam meningkatkan hasil belajar. Solusi yang dikedepankan adalah dengan penerapan model-model pembelajaran yang inovatif dalam kegiatan belajar mengajar, khususnya dalam meningkatkan kompetensi pengetahuan matematika.

Salah satu model pembelajaran yang dapat dikembangkan dalam pembelajaran Matematika adalah model pembelajaran langsung (direct instruction). Model pembelajaran langsung atau disebut juga direct instruction. Model pembelajaran ini mempunyai nama-nama yang berbeda, Archer dan Hughes (2011), "menyebutkan pembelajaran ini dengan istilah explicit instruction". Strategi explicit instruction adalah salah satu pendekatan mengajar yang dirancang khusu untuk menunjang proses belajar siswa. Kardi dan Nur (Dalam Trianto 2009:52) menyatakan juga bahwa "salah satu ciri pembelajaran langsung adalah penerapan strategi modeling". Strategi modeling adalah strategi yang dikembangkan berdasrkan prinsip bahwa seseorang dapat belajar melalui pengamatan prilaku orang. Arends (1997: 66) mengemumakakan bahwa "model pembelajaran langsung adalah model pembelajaran yang dirancang khusus untuk menunjang proses belajar siswa yang berkaitan dengan pengetahuan deklaratif dan pengetahuan prosedural yang terstruktur dengan baik yang dapat diajarkan dengna pola kegiatan yang bertahap, selangkah demi selangkah". Adapun kelebihan model pembelajaran langsun (direct instruction). Dengan kelebihan yang dimiliki model pembelajaran langsun (direct instruction), model ini dapat dijadikan salah satu model alternative dalam mengajar, agar model yang digunakan lebih bervariasi. Guru dapat memodifikasi model 
pembelajaran ini sesuai situasi dan kondisi yang terjadi saat proses pembelajaran langsung. Adapun kelebihan model pembelajaran langsung (direct instruction) yaitu : (a) guru bisa mengendalikan isi materi dan urutan informasi yang diterima oleh siswa sehingga guru dapat mempertahankan fokus apa yang harus dicapai oleh siswa, (b) dapat diterapakan secara efektif dalam kelas yang besar maupun kecil, (c) dapat digunakan untuk melakukan poin-poin penting atau kesulitan-kesulitan yang mungkin dihadapi siswa sehingga hal-hal tersebut dapat diungkapkan, (d) dapat menjadi cara yang efektif untuk mengajarkan informasidan pengetahuan factual yang sangat terstruktur, (c) merupakan cara yang efektif untuk mengajarkan konsep dan keteramppilan-keterampilan yang eksplisit kepada siswa yang berprestasi rendah, (d) dapat menjadi cara untuk menyampaikan informasi yang banyak dalam waktu yang relatif singkat dan dapat diakses secara setara oleh seluruh siswa, dan (e) guru untuk menyampaikan ketertarikan pribadi mengenai mata pelajaran (melalui prestasi yang antusias) yang dapat merangsang ketertarikan dan atusiasme siswa. (sumber?)

Sintaks Model Pengajaran langsung tersebut disajikan dalam 5 fase, seperti berikut : fase 1 menyampaikan tujuan dan mempersiapkan siswa, fase 2 mendemonstrasikan pengetahuan dan keterampilan, fase 3 membimbing pelatihan, fase 4 mengecek pemahaman dan memberikan umpan balik, fase 5 memberikan kesempatan untuk pelatihan. Dalam belajar media sangat diperlukan, dengan adanya media kesulitan-kesulitan tersebut akan dapat dihindari dan proses belajar mengajar dapat berlangsung secara optimal. Salah satu media yang dapat digunakan yaitu media gambar adalah media yang tidak diproyeksikan, media ini dapat dirancang oleh guru sendiri sesuai dengan tujuan pembelajaran yang akan dilaksanakan. Penggunaan media gambar lebih efektif apabila gambar disesuaikan dengan tingkatan anak, baik dalam hal besarnya gambar, detail, warna, dan latar belakang yang perlu untuk penafsiran. Media gambar sangat bermanfaat dalam proses pembelajaran matematika dan dapat dijadikan sebagai media yang kreatif untuk memperbaki kekurang jelasan materi. Berdasarkan uraian tersebut, dilakukan penelitian yang berjudul " Pengaruh Model Pembelajaran Langsung (Direct Instruction) Berbantuan Media Gambar Terhadap Kompetensi Penegetahaun Matematika Siswa Kelas IV SD Gugus Letda Made Putra Denpasar Utara Tahun Ajaran 2018/2019"

\section{Metode}

Penelitian yang dilaksanakan pada SD Gugus Letda Made Putra ini adalah penelitian ini merupakan jenis penelitian eksperimen semu (quasi eksperimen design) karena sulit mendapatkan kelompok kontrol yang digunakan untuk penelitian (Sugiyono,2015:114). Oleh karena itu, untuk mengatasi kesulitan dalam menentukan kelompok kontrol dalam penelitian, maka dikembangkan desain Quasi Experimental. Tidak semua variabel yang muncul dalam kondisi eksperimen dapat diukur dan dikontrol secara ketat. Variabel dapat dikontrol secara ketat yang dimaksud dalam penelitian ini pendekatan dan model pembelajaran yang diterapkan seperti model pembelajaran konvensional dan model pembelajaran langsung (direct instruction) berbantuan media gambar. Desain eksperimen yang digunakan adalah Rancangan Kelompok Kontrol Non-ekuivalen (Non-equivalent Control Group Design) merupakan rancangan penelitian yang sering digunakan dalam penelitian. Pola Rancangan Kelompok Kontrol Non-ekuivalen (Non-equivalent Control Group Design) disajikan pada gambar 1 sebagai berikut. 


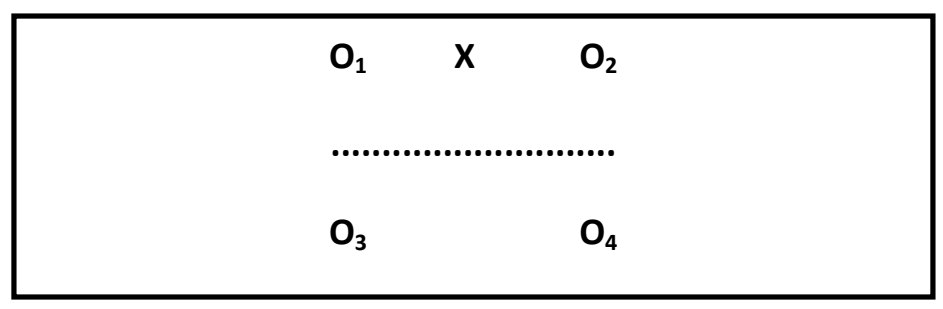

Gambar 01

Non-Equivalent Control Group Design

Keterangan :

$\begin{array}{lll}\mathrm{O} 1 & = & \text { Pre-test kelompok eksperimen } \\ \mathrm{O} 2 & = & \text { Post-test kelompok eksperimen } \\ \mathrm{O} 3 & = & \text { Pre-test kelompok kontrol } \\ \mathrm{O} 4 & = & \text { Post-test kelompok kontrol } \\ \mathrm{X} & = & \text { Perlakuan yang diberikan pada kelompok eksperimen }\end{array}$

Dalam suatu penelitian tidak lepas dari objek yang akan diteliti, seperti halnya penelitian eksperimen ini tentang Pengaruh Model Pembelajaran Langsung (Direct Intruction) Berbantuan Media Gambar Terhadap Kompetensi Pengetahuan Matematika Siswa Kelas IV SD Gugus Letda Made Putra. Subjek yang akan diteliti diistilahkan sebagai populasi dan sampel. Dalam suatu penelitian populasi dan sampel memiliki hubungan saling keterkaitan. Populasi penelitian ini adalah Kelas IV SD Gugus Letda Made Putra yang terdiri dari 6 sekolah yaitu: SDN 2 Dangin Puri (Gugus Inti), SDN 23 Dangin Puri, SDN 18 Dangin Puri, SDN 1 Tonja, SDN 2 Tonja, dan SDN 5 Tonja. Dari informasi yang diperoleh dari kepala sekolah serta guru kelas IV di masing-masing sekolah yaitu bahwa kelas IV yang ada di SD Gugus Letda Made Putra adalah homogen atau setara secara akademik. Dikatakan setara karena pengelompokan siswa ke dalam kelas-kelas dari 6 sekolah yang ada disebar secara merata antara siswa yang memiliki kemampuan tinggi, sedang dan rendah sehingga tidak terdapat kelas unggulan maupun non unggulan. Oleh karena itu semua Kelas IV dapat dijadikan populasi dalam penelitian.

Pengambilan sampel pada penelitian ini dilakukan dengan teknik random sampling, yakni yang dirandom adalah kelas. "Dalam teknik random sampling yakni teknik yang memberikan kesempatan yang sama kepada anggota populasi untuk diambil menjadi anggota sampel" (Agung, 2014:71). Teknik ini dilakukan bila anggota populasi dianggap homogen. Dengan demikian, dalam penelitian ini setiap kelas memperoleh hak yang sama dan mendapat kesempatan dipilih menjadi sampel.

Metode pengumpulan data yang digunakan dalam penelitian ini adalah metode tes. "Metode tes adalah cara memperoleh data berbentuk tugas yang diberikan dan harus dikerjakan oleh seseorang atau kelompok yang di tes" (Agung, 2014:92). Metode ini memiliki keunggulan yang lebih akurat karena tes berulang-ulang direvisi dan tes instrumen penelitian yang objektif. Kegiatan pengumpulan data dilakukan pada kelas IV di SD Gugus Letda Made Putra Denpasar Utara Tahun Ajaran 2018/2019. 
Pada penelitian ini akan dilakukan uji hipotesis dengan menggunakan teknik uji-t. Teknik uji-t dipilih karena uji-t adalah suatu tes statistik yang memungkinkan kita membandingkan dua skor rata-rata, untuk menentukan proobabilitas (peluang) bahwa perbedaan antara dua skor rata-rata merupakan perbedaan yang nyata, bukannya perbedaan yang terjadi secara kebetulan (Setyosari,2015:257) sebelum dilakukan uji hipotesis yang dianalisis dengan uji-t (ttest) terlebih dahulu dilakukan uji prasyarat analisis. Terdapat dua uji prasyarat yang harus dipenuhi sebelum dilakukan analisis data utama untuk menguji hipotesis penelitian yaitu uji normalitas dan uji homogenitas. uji normalitas sebaran data dengan menggunakan rumus ChiSquare sebagai berikut. Rumus yang digunakan adalah sebagai berikut.

$$
x^{2}=\sum \frac{(f o-f h)^{2}}{f h}
$$

Keterangan:

(Agung, 2016:99)

Fo $=$ frekuensi observasi

$\mathrm{Fh}=$ frekuensi harapan

$\Sigma=$ banyak kelas interval

Jika harga Chi-Square hitung lebih kecil daripada harga Chi-Square tabel pada taraf signifikan tertentu, maka dapat disimpulkan bahwa data tersebut berdistribusi normal. Selanjutnya uji homogenitas dapat dilakukan apabila kelompok data tersebut berdistribusi normal. Uji homogenitas varians dilakukan dengan uji F rumusnya sebagai berikut.

$F=\frac{\text { varian terbesar }\left(S_{1}^{2}\right)}{\text { varian terkecil }\left(S_{2}^{2}\right)}$

(Agung, 2016:76)

Keterangan:

$S_{1}^{2}=$ varians terbesar

$S_{2}^{2}=$ varians terkecil

Kriteria pengujian, jika $F_{\text {hit }} \geq F_{\text {tabel }}$ maka sampel tidak homogen dan jika $F_{\text {hit }}<F_{\text {tabel }}$ maka sampel homogen. Pengujian dilakukan dengan taraf signikan $5 \%$ dengan derajat kebebasan untuk pembilang $V_{1}=n_{1}-1$ dan derajat kebebasan untuk penyebut $V_{2}=n_{2-1}$ (Sugiyono, 2017). Statistik inferensial digunakan untuk menganalisis data gain skor yang dinormalisasikan dari hasil pre test dan post test. Adapun rumus yang digunakan untuk menghitung gain skor adalah sebagai berikut:

$$
G S=\frac{\text { Gain Skor }}{\text { Skor Max Ideal-Skor Pretest }}
$$

(Sumber: Dantes, 2017:126)

Keterangan:

GSn

Gain Skor

$$
\begin{aligned}
& =\text { Gain skor ternormalisasi } \\
& =(\text { Skor posttest }- \text { Skor pretest })
\end{aligned}
$$


Data yang diperoleh sudah memenuhi prasyarat uji normalitas dan homogenitas maka analisis yang digunakan adalah statistik parametrik. Analisis statistik yang digunakan untuk menguji hipotesis penelitian ini adalah uji beda mean (uji-t). Uji Hipotesis menggunakan uji-t dengan rumus separated varians. Rumus uji-t dengan separated varians digunakan bila jumlah anggota sampel sama $n_{1}=n_{2}$ dan varians homogen (Sugiyono,2017). Rumus uji-t dengan rumus separated varians sebagai berikut.

$$
t=\frac{\bar{X}_{1}-\bar{X}_{2}}{\sqrt{\frac{\left(n_{1}-1\right) S_{1}^{2}+\left(n_{2}-1\right) S_{2}^{2}}{n_{1}+n_{2}-2}\left[\frac{1}{n_{1}}+\frac{1}{n_{2}}\right]}}
$$

(Sugiyono, 2017:138)

Keterangan:

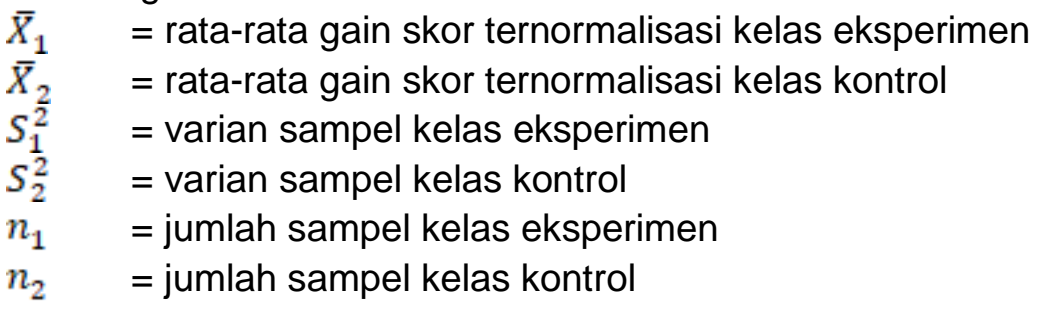

\section{Hasil dan Pembahasan}

Setelah diberikan treatment atau perlakuan menggunakna model langsung (Direct Instruction) berbantuan media gambar sebanyak 6 kali pada kelompok eksperimen selanjutnya pada akhir penelitian diberikan post test untuk memperoleh kompetensi pengetahuan matematika siswa. Hasil data kompetesi pengetahuan matematika siswa pada kelompok eskperimen selanjutnya dianalsis. Diperoleh data kemampuan berhitung matematika kelompok eksperimen adalah 81,4 .

Setelah diberikan treatment atau perlakuan menggunakan model pembelajaran konvensional sebanyak 6 kali pada kelompok kontrol selanjutnya pada akhir penelitian diberikan post test untuk memperoleh kompetensi pengetahuan matematika siswa. Diperoleh data kompetensi pengetahuan matematika kelompok kontrol adalah 56,9.

Terdapat dua uji prasyarat yang harus dipenuhi sebelum dilakukan analisis data utama untuk menguji hipotesis penelitian yaitu uji normalitas sebaran data tiap kelompok dan uji homogenitas varians antar kelompok. Uji normalitas sebaran data adalah untuk mengetahui apakah uji hipotesis dengan statistik parametris dapat dilakukan atau tidak. Apabila sebaran data sudah berdistribusi normal, maka uji lanjut dengan menggunakan statistik parametrik dapat dilakukan. Sedangkan, bila data tidak berdistribusi normal maka uji lanjut menggunakan statistik parametris tidak dapat dilakukan dan harus beralih menggunakan statistik non parametris. Untuk mengetahui apakah sebaran data berdistribusi normal atau tidak, maka akan dilakukan uji normalitas sebaran data dengan menggunakan rumus Chi Square. Dapat dilihat pada tabel 1. 
Tabel 01. Rangkuman Hasil Uji Normalitas Sebaran Data

\begin{tabular}{|c|c|c|c|c|}
\hline No & $\begin{array}{l}\text { Kelompok Data } \\
\text { Matematika }\end{array}$ & Belajar $\chi_{\text {hitung }}^{2}$ & $\chi_{\text {tabel }}^{2}$ & Status \\
\hline 1 & Post-test Kelas Eksperimen & 2,40 & 11,07 & Normal \\
\hline 2 & Post-test Kelas Kontrol & 5,00 & 11,07 & Normal \\
\hline
\end{tabular}

Kriteria pengujian, jika $\chi^{2}{ }_{h i t}<\chi_{\text {tab }}^{2}$ dengan taraf signifikasi $5 \% \quad(\mathrm{dk}=$ jumlah kelas dikurangi parameter, dikurangi 1), maka data berdistribusi normal. Sedangkan, jika $\chi_{h i t}^{2} \geq \chi_{\text {tab }}^{2}$, maka sebaran data tidak berdistribusi normal. Berdasarkan hasil perhitungan degan menggunakan rumus Chi-Square, diperoleh data hasil post-test kelompok eksperimen dan kontrol berdistribusi normal. Selanjutnya uji homogenitas dilakukan untuk menunjukan bahwa perbedaan yang terjadi pada uji hipotesis benar-benar terjadi akibat adanya perbedaan varians antar kelompok, bukan sebagai akibat perbedaan dalam kelompok. Uji homogenitas dapat dilakukan apabila kelompok data tersebut berdistribusi normal. Uji homogenitas varians dilakukan dengan uji $F$. Kriteria pengujian, jika $F_{\text {hit }} \geq F_{\text {tabel }}$ maka sampel tidak homogen dan jika $F_{\text {hit }}<F_{\text {tabel }}$ maka sampel homogen. Pengujian dilakukan dengan taraf signikansi $5 \%$ dengan derajat kebebasan untuk pembilang $V_{1}=n_{1}-1$ dan derajat kebebasan untuk penyebut $V_{2}=n_{2}-1$. Rekapitulasi hasil uji homogenitas varians antar kelompok eksperimen dan kontrol disajikan pada tabel 2 di bawah ini.

\begin{tabular}{cccc}
\multicolumn{4}{c}{ Tabel 02 Hasil Uji Homogenitas Varians } \\
\hline Data & $\mathbf{F}_{\text {hitung }}$ & $\mathbf{F}_{\text {tabel }}$ & Kesimpulan \\
\hline $\begin{array}{c}\text { Post-test Kelompok Eksperimen dan } \\
\text { Kelompok Kontrol }\end{array}$ & 1,01 & 1,93 & Homogen \\
\hline
\end{tabular}

Berdasarkan tabel di atas, diketahui $F_{\text {hitung }}$ hasil kelompok eksperimen dan kontrol adalah 1,01 sedangkan $F_{\text {tabel }}$ pada $\mathrm{db}_{\text {pembilang }}=40, \mathrm{db}_{\text {penyebut }}=31$, dan taraf signifikansi $5 \%$ adalah 1,93. Hal ini berarti, varians data kompetensi pengetahuan matematika kelompok eksperimen dan kontrol adalah homogen. Sebelum melakukan pengujian uji-t terlebih dahulu dianalisis data dengan menggunakan rumus gain score yang dinormalisasikan dari hasil pre test dan post test dengan syarat data pada kelas eksperimen dan kontrol harus normal dan homogen. Adapun rumus yang digunakan untuk menghitung gain score adalah sebagai berikut:

$$
G S n=\frac{\text { Gain Score }}{\text { Score max }- \text { Score pretest }}
$$

Setelah melakukan perhitungan perhitungan diperoleh gain skor kelompok eksperimen adalah 0,523 dan kelompok kontrol adalah 0,232. Data yang telah diuji normalitasnya dan homogenitasnya selanjutnya dilakukan uji hipotesisnya. Kriteria pengujian jika $\mathrm{H}_{0}$ ditolak dan $\mathrm{H}_{1}$ diterima ini berarti, terdapat perbedaan yang signifikan. Tetapi jika $\mathrm{H}_{0}$ diterima dan $\mathrm{H}_{1}$ ditolak ini berarti, tidak terdapat perbedan yang signifikan. Pengujian dilakukan dengan taraf signifikansi $5 \%$ dengan derajat kebebasan $\mathrm{dk}=\mathrm{n} 1+\mathrm{n} 2-2$. Rangkuman hasil analisis uji-t ditampilkan pada tabel 3 berikut. 


\begin{tabular}{lccccc}
\multicolumn{6}{c}{ Tabel0 3 Hasil Uji-T } \\
\hline Kelompok & $\mathbf{N}$ & Db & Mean & $\mathbf{t}_{\text {hit }}$ & $\mathbf{t}_{\text {tab }}$ \\
\hline Eksperimen & 41 & & 0,601 & \\
Kontrol & 32 & 71 & 0,207 & 5,998 & 2,000 \\
\hline
\end{tabular}

Berdasarkan tabel analisis di atas, dapat diketahui $t_{\text {hitung }}=5,998$ dan $t_{\text {tabel }}=2,000$ untuk $\mathrm{db}=71$ pada taraf signifikansi $5 \%$. Berdasarkan kriteria pengujian, karena $t_{\text {hitung }}>t_{\text {tabel }}$ maka $H_{0}$ ditolak dan $\mathrm{H}_{1}$ diterima. Artinya, terdapat pengaruh secara signifikan kompetensi pengetahuan matematika antara siswa yang dibelajarkan dengan model pembelajaran langsung (direct instruction) berbantuan media gambar dengan siswa yang dibelajarkan melalui pembelajaran konvensional.

Berdasarkan hasil penelitian yang diperoleh dari kelompok eksperimen yang dibelajarkan menggunaan model langsung (direct instruction) berbantuan media gambar dan dari kelompok kontrol yang dibelajarkan melalui pembelajaran konvensional. Kelompok eksperimen dan kelompok kontrol diberikan perlakuan dan setelah perlakuan kedua kelompok diberikan post test untuk mendapatkan data kompetensi pengetahuan matematika pada kelompok eksperimen dan kontrol. Setelah menganilisis data post test yang diperoleh nilai ratarata kompetensi pengetahuan matematika pada kedua kelompok yaitu pada kelompok eksperimen 81,4 dan pada kelompok kontrol 56,9. Dari hasil perhitungan bahwa diketahui sebaran data post test sebaran data pada kelompok ekperimen dan kelompok kontrol normal dan homogen. Dari hasil analisis diperoleh $t_{\text {hitung }} 5,998$. Harga tersebut dibandingkan dengan $t_{\text {tabel }}$ dengan $\mathrm{dk}=41+32-2=71$ dengan taraf signifikansi $5 \%$ adalah 2,000 maka Ho ditolak. Hal ini berarti terdapat pengaruh secara signifikan kompetensi pengetahuan matematika antara siswa yang dibelajarkan dengan model pembelajaran langsung (direct instruction) berbantuan media gambar dengan siswa yang dibelajarkan melalui pembelajaran konvensional. Adanya perbedaan yang signifikansi menunjukkan bahwa model pembelajaran langsung (direct instruction) berpengaruh terhadap kompetensi pengetahuan matematika siswa. Pengaruh model pembelajaran konvensional dapat dilihat pada statistik deskriptif antara kedua kelompok sampel. Secara deskriptif, rata-rata kompetensi pengetahuan matematika siswa kelompok ekperimen lebih tinggi yaitu 81,4 dibandingkan dengan rata-rata kompetensi pengetahuan matematika kelompok kontrol sebesar 56,9.

Perbedaan hasil yang signifikan terhadap kompetensi pengetahuan matematika siswa yang dibelajarkan dengan model pembelajaran langsung (direct instruction). Model direct instruction ini merupakan model pembelajaran yang dimana siswa banyak mendapat pengetahuan dari pengamatan dan meniru tingkah laku orang lain. Model pembelajaran ini membantu siswa dalam memperoleh pengetahuan prosedural dan deklaratif (factual) dan diajarakan tahap demi tahap. Direct instruction menggunakan gabungan peragaan dan penjelasan dari guru dengan latihan dan umpan balik dari siswa untuk mendaptkan pengetahuan dan keterampilan lebih jauh. Model direct instruction merupakan model pengajaran yang bersifat teacher center atau berpusat pada guru, sehingga guru menjadi model utama pada model ini, maka dari itu guru harus pandai-pandai dalam menyampaikan materi pembelajaran dan membuat pembelajaran seefektif mungkin dan menyenangkan bagi anak dibantu oleh adanya media pembelajaran yang unik dan bervariasi.

Dapat disimpulkan bahwa model direct instruction ini merupakan model pembelajaran yang dimana siswa banyak mendapat pengetahuan dari pengamatan dan meniru tingkah laku orang lain. Model pembelajaran ini membantu siswa dalam memperoleh pengetahuan 
prosedural dan deklaratif (factual) dan diajarakan tahap demi tahap. Agar lebih menarik minat siswa dalam mengikuti proses pembelajaran model pembelajaran langsung (direct instruction) maka dipadukan dengan media gambar. Media gambar adalah media yang paling umum dipakai, hal ini dikarenakan siswa menyukai gambar, apalagi jika gambar dibuat dan disajikan sesuai dengan persyaratan yang baik, sudah tentu akan menambah semangat siswa dalam mengikuti proses pembelajaran. Hal ini berbeda dengan siswa yang dibelajarkan dengan model pembelajaran konvensional pada kelas kontrol. Pembelajaran mencirikan pembelajaran yang berpusat pada guru. Secara teoritis, pembelajaran yang menggunakan model konvensional adalah pembelajaran dengan metode ceramah, karena sejak dulu metode ini telah dipergunakan sebagai alat komunikasi lisan antara guru dengan anak didik dalam proses belajar dan mengajar. Dalam hal ini, terlihat bahwa pembelajaran kurang maksimal dalam meningkatkan kompetensi pengetahuan matematika siswa.

Hasil penelitian yang terkait dalam penelitian ini adalah yang dilakukan oleh Ayu Dewi Mastika (2013) yang menyimpulkan bahwa pelaksanaan pembelajaran dilakukan melalui penerapan pembelajaran explicit instruction berpengaruh terhadap hasil belajar IPA siswa kelas V tahun pelajaran 2012/2013 di Gugus I Kecamatan Buleleng. Karena model pembelajaran langsung (direct instruction) dapat membantu siswa dalam memperoleh pengetahuan prosedural dan deklaratif (factual) dan diajarakan tahap demi tahap. Selain itu didukung Rahmawati Utari (2016) yang menyimpulkan bahwa penerapan model pembelajaran Explicit Instruction berbantuan lingkungan alam sekitar berpengaruh positif terhadap hasil belajar IPA siswa kelas IV di MIN Air Kuning tahun pelajaran 2015/2016. Selain itu, dengan menggunakan bantuan media gambar dalam proses pembelajaran siswa lebih cepat memahami pembelajaran dan tidak bosan dalam proses pembelajaran. Dimana media gambar mudah dipahami oleh siswa. Berdasarkan pemaparan tersebut, dapat disimpulkan bahwa model pembelajaran langsung (direct instruction) berbantuan media gambar berpengaruh terhadap kompetensi pengetahuan matematika siswa kelas IV SD Gugus Letda Made Putra Denpasar Utara Tahun Ajaran 2018/2019.

\section{Simpulan dan Saran}

Berdasarkan hasil analisis data dan pembahasan yang telah dipaparkan diperoleh hasil uji hipotesis dengan menggunakan uji-t dimana diperoleh $t_{\text {hitung }}=5,998$ dan dengan taraf signifikansi $5 \%$, $\mathrm{dk}=41+32-2=71$ diperoleh $t_{\text {tabel }}=2,000$. Dengan demikian, nilai $t_{\text {hitung }}>t_{\text {tabel }}$ sehingga Ho ditolak. Nilai rata-rata kompetensi pengetahuan matematika kelompok eksperimen $=81,4$, sedangkan nilai rata-rata kompetensi pengetahuan matematika kelompok kontrol $=56,9$. Sehingga nilai rata-rata kompetensi pengetahuan matematika kelompok eksperimen lebih tinggi dibandingkan kompetensi pengetahuan matematika kelompok kontrol yaitu 81,4 > 56,9. Jadi dapat disimpulkan bahwa model pembelajaran langsung (direct instruction) memberikan pengaruh terhadap kompetensi pengetahuan matematika kelas IV SDN Gugus Letda Made Putra Denpasar Utara.

Berkenaan dengan hasil penelitian yang diperoleh maka dapat diajukan beberapa saran sebagai berikut. Saran yang dapat disampaikan berdasarkan penelitian yang telah dilakukan adalah sebagai berikut : 1) Kepada Siswa diharapkan siswa dapat lebih aktif, kreatif, dapat selalu meningkatkan rasa ingin tahu melalui bertanya apabila ada yang belum di pahami, agar pengembangan pola pikir siswa dapat lebih luas, kritis dan inovatif. 2) Kepada guru, disarankan untuk lebih kreatif dalam memberikan fasilitas pendukung berupa inovasi pelaksanaan pembelajaran dengan menerapkan model pembelajaran langsung (direct instruction) 
berbantuan media gambar sehingga tercipta pembelajaran yang bermakna dan semangat siswa untuk belajar meningkat. 3) Kepala sekolah disarankan agar dapat menggunakan hasil penelitian ini sebagai pendukung sumber belajar guru dalam meningkatkan kualitas pembelajaran dengan menciptakan pembelajaran yang menyenangkan di sekolah. 4) Peneliti lain disarankan agar memanfaatkan hasil penelitian ini sebagai referensi untuk melaksanakan

\section{Daftar Pustaka}

Agung, Gede A dkk. 2016. "Analisis Buku Tkes Siswa Kurikulum 2013 Ditinju dari Aspek Desain Pesan Pembelajaran Kelas IV Sekolah Dasar". e-Journl Edutech, 5(2):

Agung, A. A. G. (2013). Evaluasi Pendidikan. Singaraja: Undiksha.

Amir, Almira. Pengguna Media Gambar dalam Pembelajaran Matematika : JURNAL EKSAKTA (VOLUME 2 NOMOR 1, 2016) (diakses pada tanggal 14 April 2019)

Archer, A. L., \& Hughes, C. A. (2011). Explicit instruction: Effective and efficient teaching . New York: Guilford Press.

Arends 1997. Model-Model Pembelajaran Inovatif berorientasi Konstuktivitis, Jakarta: Prestasi Pustaka Publisher

Dantes, Nyoman. 2017. Desain Eksperiman dan Analisis Data, Depok: PT Rajagrafindo Persada

Depdiknas .2001. Kamus Besar Bahasa Indonesia.Jakarta ;Balai Pustaka.

Huda, Miftahul. 2017. Model - Model Pengajaran dan Pembelajaran, Yogyakarta: Pustaka Pelajar.

Kosasih, E. 2016. Strategi Belajar Dan Pembelajaran Implementasi Kurikulum 2013, Bandung: Yrama Widya.

Koyan, Wayan. 2012. Statistik Pendidikan Teknik Analisis Data Kuantitatif. Bali: Universitas Pendidikan Ganesha Press.

Kurniasih, Sani. 2014. Strategi - Strategi Pembelajaran. Alfabeta:Bandung.

Mastika, Ayu Dewi. Pengaruh Model Pembelajaran Explicit Instruction Berbantuan Media Gambar Terhadap Hasil Belajar IPA Kelas V SD Gugus I Kecamatan Buleleng : Jurnal Mimbar IImu Universitas Pendidikan Ganesha. (diakses pada tanggal 29 Januari 2019)

Permendikbud Nomor 104 Tahun 2014 tentang Penilaian Hasil Belajar Oleh Pendidik Pada Pendidikan Dasar dan Pendidikan Menengah.

Rosmala, Amelia \& Atun, Isrok. 2018. Model - Model Pembelajaran Matematika. Jakarta: PT Bumi Aksara.

Setyosari, Punaji.2015. Metode Penelitian Pendidikan dan Pengembangan Edisi ke Empat. Jakarta: Prenadamedia Group. 
Sugiyono (2015). Metode Penelitian Kombinasi (Mix Methods). Bandung: Alfabeta.

Sugiyono (2017). Metode Penelitian Kualitatif: Untuk penelitian yang bersifat: eksploratif, enterpretif, interaktif, dan konstruktif. Bandung: Alfabeta

Susanto, Ahmad. (2014). Teori Belajar \& Pembelajaran di Sekolah dasar. Jakarta: Prenadamedia Grup.

Trianto. 2009. Medesain Model Pembelajaran Inovatif-Progresift, Jakarta: 13220 